Shakespearean

Intersections 
This page intentionally left blank 


\section{Shakespearean Intersections}

Language, Contexts,

Critical Keywords

\section{Patricia Parker}

\section{$\overline{\text { PENN }}$}

UNIVERSITY OF PENNSYLVANIA PRESS P H I L A DE L P H I A 
A volume in the Haney Foundation Series, established in 196I with the generous support of Dr. John Louis Haney.

Copyright (C) 2018 University of Pennsylvania Press

All rights reserved. Except for brief quotations used for purposes of review or scholarly citation, none of this book may be reproduced in any form by any means without written permission from the publisher.

Published by University of Pennsylvania Press Philadelphia, Pennsylvania I9IO4-4II2 www.upenn.edu/pennpress

Printed in the United States of America on acid-free paper I 3579 IO 8642

\section{Library of Congress Cataloging-in-Publication Data}

Names: Parker, Patricia A., author.

Title: Shakespearean intersections : language, contexts, critical keywords / Patricia Parker.

Other titles: Haney Foundation series.

Description: Ist edition. | Philadelphia : University of Pennsylvania Press, [2018] | Series: Haney Foundation series, | Includes bibliographical references and index.

Identifiers: LCCN 2017054846 | ISBN 978-0-8I22-4974-3 (hardcover : alk. paper)

Subjects: LCSH: Shakespeare, William, 1564-I616-Language. | Shakespeare, William, I564-I616-Literary style. | English language-Early modern, I500-I700-Style. | English language-Early modern, I500-1700-Semantics.

Classification: LCC PR3072 .P37 2018 | DDC 822.3/3-dc23

LC record available at https://lccn.loc.gov/20I7054846 


$$
\text { For }
$$

my now extended family, with love 
This page intentionally left blank 